\title{
A CIÊNCIA EM TEMPOS DE PANDEMIA
}

SCIENCE IN PANDEMIC TIMES

Raimundo Nonato Ribeiro dos Santos ${ }^{1}$

A pandemia de COVID-19, que se estabeleceu no mundo nesse ano de 2020, é um daqueles pontos de ruptura que marcam a história da humanidade, assim como a descoberta do fogo, a invenção da imprensa, a Revolução Francesa, a Revolução Industrial, as guerras mundiais, entre outros momentos. Em comum, ambos permitiram um salto na evolução e sobrevivência da humanidade, transformando toda a sua organização social e esferas como a Educação, a Ciência, o Meio Ambiente, a Política e as relações de Trabalho.

No contexto atual, destacamos o papel da Ciência no enfrentamento de duas pandemias concomitantes: a de COVID-19 e a de fakenews. A comunidade científica assumia o front e o protagonismo no combate ao vírus Sars-CoV-2, alertando sobre o contágio, orientando na prevenção da doença, quanto ao uso de máscaras, uso de água, sabão e álcool em gel, lockdown e isolamento social, agindo com rapidez em seus laboratórios na sequência do genoma viral, deteç̧ão dos sintomas, entendimento da ação do vírus no corpo humano, desenvolvimento de testes de diagnóstico, e, em tempo recorde (menos de um ano), conseguiu desenvolver e produzir vacinas para imunizar a população.

Enquanto isso, tínhamos a disseminação de informações inverídicas em grupos de Whatsapp, canais no Youtube e na internet em geral. Uma pesquisa sobre desinformação e pandemia no Brasil, Itália e Estados Unidos, desenvolvida pela ONG Avaaz ${ }^{2}$, revelou que pelo menos $94 \%$ dos brasileiros teve acesso a pelo menos uma das notícias falsas sobre o Corona Vírus mostradas pela pesquisa. Destes, $73 \%$ acreditaram, total ou parcialmente, nas informações falsas.

\footnotetext{
${ }^{1}$ Doutor em Ciência da Informação pela Universidade Federal da Paraíba (UFPB). Bibliotecário da Universidade Federal do Ceará (UFC). Orcid ID: https://orcid.org/0000-0002-2829-769X. Lattes ID: http://lattes.cnpq.br/1946724751658685. E-mail: nonatobiblio@gmail.com.

2 Fonte: https://bit.ly/38Ni3CU. Acesso em: 28 dez. 2020.
} 
Tal negacionismo científico é muitas vezes conduzido por líderes políticos que minimizam a gravidade da doença, não seguem os protocolos mundialmente recomendados, compartilham desinformação, incentivam aglomerações, receitam o uso de medicação sem nenhuma comprovação científica, se omitem no desenvolvimento de políticas públicas, deliberadamente ou por inépcia, permitindo o esgotamento do Sistema Único de Saúde.

Diferentemente, a Ciência firma-se nesse cenário, sendo pautada pelo método, rigor e formalidade, baseada em dados e informações, avaliadas pelos pares, em busca de verdades, ainda que transitórias, aproximativas e verificáveis.

Ademais, a pandemia trouxe a Ciência para a sala do cidadão comum. Tornou-se habitual entrevistas com cientistas na televisão, rádio, jornal e lives em mídias sociais. Era necessário explicar a doença, formas de contágio, que não era só uma "gripezinha", reforçar repetidamente o porquê do uso da máscara, do isolamento social, como funcionavam os testes, as etapas no desenvolvimento de uma vacina e que esta não transformaria ninguém em "jacaré". Algumas dessas pautas eram obviedades necessárias em tempos de terraplanismo, negacionismo científico e expansão do movimento antivacina, mas que permitiram que a Ciência se aproximasse e dialogasse com a sociedade, firmando-se como a protagonista global na busca de soluções eficazes e seguras.

O mundo iniciará o ano 2021 tendo que lidar com a chegada de uma segunda onda de infecção, possível mutação do vírus, mas também o início da vacinação, com os governos lidando com a retomada do trabalho, educação e serviços de saúde, fomentando o empreendedorismo e a economia, tudo reconfigurado para a Era Pós-Pandemia.

A Ciência mostrou-se essencial para a humanidade, expandindo a compreensão sobre o Corona Vírus, atuando na prevenção de novas pandemias, refinando seus processos de desenvolvimento de vacinas e buscando compreender as novas dinâmicas sociais nesse mundo pós-pandemia. Seguirá avançando, dando continuidade ao uso de estratégias inovadoras como a formação de forças-tarefas para pesquisas específicas, a cooperação internacional e o compartilhamento de dados entre instituições e/ou países.

$\mathrm{E}$, nesse sentido, publicar o novo número de uma revista científica é atestar o protagonismo da Ciência em tempos de pandemia de Corona Vírus e fakenews, sendo um ato de resistência da academia na luta contra o negacionismo científico. 